\title{
Bone marrow non-mesenchymal mononuclear cells induce functional differentiation of neuroblastoma cells
}

\author{
Chareerut Phruksaniyom ${ }^{1}$ Permphan Dharmasaroja ${ }^{1 *}$ and Surapol Issaragrisil|
}

\begin{abstract}
Less is known about the non-mesenchymal mononuclear cell fraction of human bone marrow on functional adaptation of neuroblastoma cells. Using immunocytochemistry, we showed that bone-marrow mononuclear cell (BMMC)-conditioned medium can induce tyrosine hydroxylase expression in neuroblastoma cells, which is similar to the effect of retinoic acid. Using quantitative RT-PCR, we showed that NGF, CNTF, and BDNF mRNAs were detected in unfractionated BMMC populations from all human donors at different expression levels. Our results suggest that cells of the non-mesenchymal mononuclear cell fraction can induce functional adaptation of neuroblastoma cells, probably via their secreted trophic factors.
\end{abstract}

Keywords: Bone-marrow mononuclear cells, Neuroblastoma cells, Tyrosine hydroxylase, Trophic factors, Neuronal differentiation

\section{To the editor}

Many studies investigating the possible therapeutic role of bone marrow-derived stem cells (BMDCs) used a specific subpopulation: the bone marrow mesenchymal stromal cells (MSCs) obtained after several weeks in cultures [1], or the mononuclear fraction (BMMC; bone marrow mononuclear cells) obtained immediately after aspiration. Cells of the hematopoietic stem cell fraction, when transplanted into lesions of a developing spinal cord in a chicken embryo, can differentiate into neurons [2]. The capacity of BMMCs to generate neural cells is poorly characterized. Several studies indicate an overlap in the molecular programs for hematopoiesis and neuropoiesis in mice $[3,4]$. Primary CD34+ human hematopoietic stem cells (HSCs) have been shown to express mRNA for a number of proteins that are used by neurons [5].

Evidence has indicated that human SH-SY5Y neuroblastoma cells changed into neuron-like phenotypes with reduced proliferation by all-trans retinoic acid (ATRA) [6], and treatment with RA increased protein expression

\footnotetext{
* Correspondence: permphan.dha@mahidol.ac.th

${ }^{1}$ Department of Anatomy, Faculty of Science, Mahidol University, Rama VI Road, Ratchathewi, Bangkok 10400, Thailand

Full list of author information is available at the end of the article
}

of tyrosine hydroxylase (TH) in neuroblastoma cells [7]. Using a co-culture method, human MSCs promoted the survival and neuritogenesis of neuroblastoma cells, similar to that of ATRA [8]. Less is known about the mononuclear cell fraction of human bone marrow on functional adaptation of neuroblastoma cells.

We hypothesize that cells of the BMMC fraction can induce functional adaptation of neuroblastoma cells, probably via their secreted trophic factors. First, we evaluated the effect of cells of the human BMMC fraction on the expression of $\mathrm{TH}$ protein in neuroblastoma cells by culturing $\mathrm{SH}-\mathrm{SY} 5 \mathrm{Y}$ cells in BMMC-conditioned medium. Human bone marrow samples were aspirated from healthy donors after obtaining informed consent and ethical approval by the Siriraj Ethics Committee of Siriraj Hospital. After isolation, the mononuclear cells were plated at a concentration of $1.5 \times 10^{5}$ cells $/ \mathrm{ml}$ onto flasks containing low glucose-DMEM supplemented with $10 \%$ fetal bovine serum (FBS). After incubation for $72 \mathrm{~h}$, non-adherent cells were collected for culture in MEM/F12 medium supplemented with 10\% FBS. After an additional $24 \mathrm{~h}$, non-adherent cells were collected again and cultured in the medium as described above. After $24 \mathrm{~h}$, non-adherent cell-conditioned medium was collected for further experiment. SH-SY5Y cells were

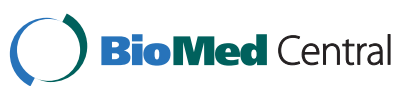

(c) 2013 Phruksaniyom et al.; licensee BioMed Central Ltd. This is an Open Access article distributed under the terms of the Creative Commons Attribution License (http://creativecommons.org/licenses/by/2.0), which permits unrestricted use, distribution, and reproduction in any medium, provided the original work is properly cited. 


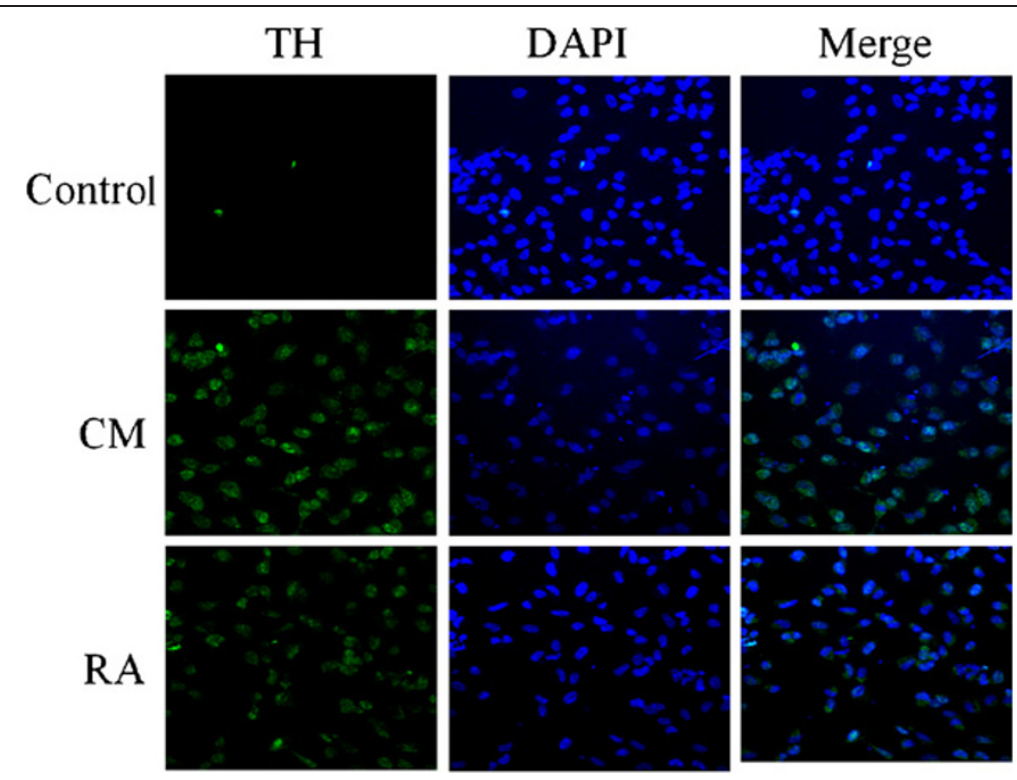

Figure 1 Immunostaining micrographs using a confocal microscope demonstrate localization of the tyrosine hydroxylase (TH). Cells were stained with polyclonal antibody against TH and immunostained with Alexa 488-conjugated secondary antibody (green) and nuclei were stained with DAPI (blue). CM, BMMC-conditioned medium; RA, retinoic acid.

then seeded onto plates containing BMMC-conditioned medium at an initial density of $1 \times 10^{4}$ cells $/ \mathrm{ml}$, and cultures were maintained for 7 days prior to analysis of $\mathrm{TH}$ expression using immunocytochemistry. As a positive control, cells were treated with $10 \mu \mathrm{M}$ ATRA for 5 days to induce neuronal differentiation. With estimated concentration of $35 \pm 2 \times 10^{4}$ cells/ml for staining, the results showed that BMMC-conditioned medium can induce $\mathrm{TH}$ protein expression in neuroblastoma cells (Figure 1C), which is similar to the effect of ATRA (Figure 1B). Untreated cells did not express $\mathrm{TH}$ or expressed at very low levels (Figure 1A).

Further, we evaluated whether cells of the BMMC fraction expressed any trophic factors that could contribute to biochemical adaptation of neuroblastoma cells. Monocytes in the human bone marrow have been shown to produce nerve growth factor (NGF), which plays an important role in neuronal plasticity, maturation, and survival [9]. Human monocytes, T cells, and B cells can secrete brain-derived neurotrophic factor (BDNF), a member of the neurotrophin family that regulates the differentiation and survival of various neuronal populations [10]. Ciliary neurotrophic factor (CNTF), another factor involved in neurogenesis, is also expressed in monocytes, myeloid cells, lymphoblasts, $\mathrm{T}$ cells and B cells [11]. Here, we evaluated the mRNA expression of NGF, BDNF, and CNTF in BMMCs using quantitative RT-PCR. The sequences of the sense and antisense primers are as follows: NGF: TAAAAAGCGGCGACT CCGTT and ATTCGCCCCTGTGGAAGATG; CNTF: ACCAGCAGGTGCATTTTACC and GAAACGAAGG
TCATGGATGG; BDNF: ACTCTGGAGAGCGTGAA TGG and ATCCAACAGCTCTTCTATCACG; $\beta$-actin: CATGTACGTTGCTATCCAGGC and CTCCTTAATG TCACGCACGAT. The results showed that NGF, CNTF, and BDNF mRNAs were detected in unfractionated BMMC populations from all donors at different expression levels (Figure 2). Their expression levels were rather low, suggesting that not all but only some populations of the cells expressed these trophic factors.

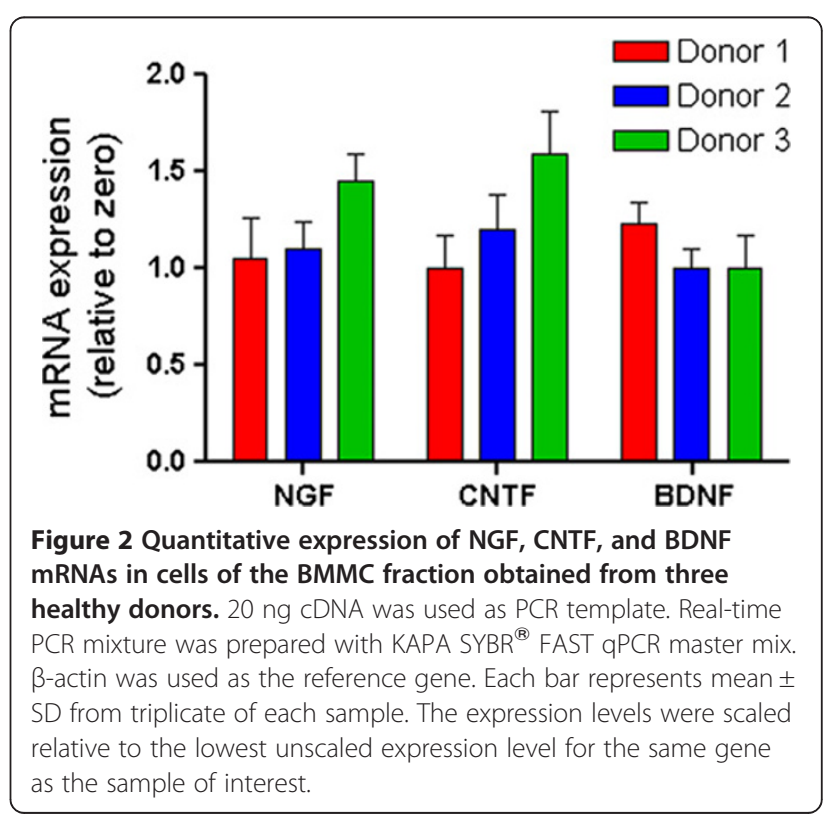


Expression of $\mathrm{TH}$, the enzyme involved in the first step of the biosynthesis pathway of dopamine and noradrenaline, in SH-SY5Y cells by BMMC-conditioned media suggests the functional differentiation of the cells. ATRA can also induce responsiveness to BDNF in $\mathrm{SH}-$ SY5Y cells [12]. Our results imply that expression and secretion of BDNF from cells in the mononuclear fraction may explain the similar effects of RA and BMMCconditioned media. BMDCs constitutively synthesize and secrete NGF, BDNF, and CNTF. Multiple cell types, however, are present in the BMMC fraction. Primary CD34+ human HSCs express mRNA for a number of proteins, including receptors for trophic factors and other mediators involved in the development of neurons [5]. Most of the CD34+ cells are progenitors for myeloid and lymphoid lineages, which express some trophic factors, such as CNTF [11], that were also observed in our quantitative RT-PCR results. Further studies are required to quantify the contribution of trophic factors to BMMC-induced effects on functional adaptation of neuroblastoma cells, which could have clinical relevance in treatment of neuroblastoma.

\section{Competing interests}

The authors declare that they have no competing interests.

\section{Authors' contributions}

PD was involved in the design and execution of the experiments, performed data and statistical analyzes, wrote the manuscript and contributed to overall experiment design. CP conducted immunocytochemistry and quantitative RT-PCR. SI provided bone marrow samples and submitted the project for ethical approval. All authors have read and approved the final manuscript.

\section{Acknowledgments}

This work was supported by a grant from Faculty of Science, Mahidol University to PD.

\section{Author details}

'Department of Anatomy, Faculty of Science, Mahidol University, Rama VI Road, Ratchathewi, Bangkok 10400, Thailand. ²Division of Hematology, Department of Medicine, Faculty of Medicine Siriraj Hospital, Mahidol University, Bangkok 10700, Thailand.

Received: 14 January 2013 Accepted: 16 March 2013

Published: 3 April 2013

\section{References}

1. Wang S, Qu X, Zhao RC: Clinical applications of mesenchymal stem cells. J Hematol Oncol 2012, 5:19.

2. Sigurjonsson OE, Perreault MC, Egeland T, Glover JC: Adult human hematopoietic stem cells produce neurons efficiently in the regenerating chicken embryo spinal cord. Proc Natl Acad Sci USA 2005, 102:5227-5232.

3. Terskikh AV, Easterday MC, Li L, Hood L, Kornblum HI, Geschwind DH, et al: From hematopoiesis to neuropoiesis: evidence of overlapping genetic programs. Proc Natl Acad Sci USA 2001, 98:7934-7939.

4. Goolsby J, Marty MC, Heletz D, Chiappelli J, Tashko G, Yarnell D, et al: Hematopoietic progenitors express neural genes. Proc Natl Acad Sci USA 2003, 100:14926-14931.

5. Steidl U, Bork S, Schaub S, Selbach O, Seres J, Aivado M, et al: Primary human $\mathrm{CD} 34+$ hematopoietic stem and progenitor cells express functionally active receptors of neuromediators. Blood 2004, 104:81-88.
6. Miloso M, Villa D, Crimi M, Galbiati S, Donzelli E, Nicolini G, et al: Retinoic acid-induced neuritogenesis of human neuroblastoma SH-SY5Y cells is ERK independent and PKC dependent. J Neurosci Res 2004, 75:241-252.

7. Kume T, Kawato Y, Osakada F, Izumi Y, Katsuki H, Nakagawa T, et al: Dibutyryl cyclic AMP induces differentiation of human neuroblastoma SH-SY5Y cells into a noradrenergic phenotype. Neurosci Lett 2008, 443:199-203.

8. Crigler L, Robey RC, Asawachaicharn A, Gaupp D, Phinney DG: Human mesenchymal stem cell subpopulations express a variety of neuroregulatory molecules and promote neuronal cell survival and neuritogenesis. Exp Neurol 2006, 198:54-64.

9. Caroleo MC, Costa N, Tirassa P, Aloe L: Nerve growth factor produced by activated human monocytes/macrophages is severely affected by ethanol. Alcohol 2004, 34:107-114.

10. Kerschensteiner M, Gallmeier E, Behrens L, Leal W, Misgeld T, Klinkert WE, et al: Activated human T cells, B cells, and monocytes produce brainderived neurotrophic factor in vitro and in inflammatory brain lesions: a neuroprotective role of inflammation? J Exp Med 1999, 189:865-870.

11. Su Al, Wiltshire T, Batalov S, Lapp H, Ching KA, Block D, et al: A gene atlas of the mouse and human protein-encoding transcriptomes. Proc Natl Acad Sci USA 2004, 101:6062-6067.

12. Edsjo A, Lavenius E, Nilsson H, Hoehner JC, Simonsson P, Culp LA, et al: Expression of trkB in human neuroblastoma in relation to MYCN expression and retinoic acid treatment. Lab Invest 2003, 83:813-823.

doi:10.1186/2162-3619-2-9

Cite this article as: Phruksaniyom et al:: Bone marrow non-mesenchymal mononuclear cells induce functional differentiation of neuroblastoma cells. Experimental Hematology \& Oncology 2013 2:9.

\section{Submit your next manuscript to BioMed Central and take full advantage of:}

- Convenient online submission

- Thorough peer review

- No space constraints or color figure charges

- Immediate publication on acceptance

- Inclusion in PubMed, CAS, Scopus and Google Scholar

- Research which is freely available for redistribution 